\title{
Pandangan Guru MA Nurul Iman Mamben Lauk terhadap Pelaksanaan Pembelajaran berbasis High Order Thingking Skill (HOTS)
}

\author{
${ }^{1}$ Anggun Variasi Islami, M. Abdurrahman Sunni \\ ${ }^{1}$ Teknik Komputer, UTM Mataram \\ ${ }^{2}$ Teknik Informatika, UTM Mataram \\ Email $^{1}$ variasi.anggun@gmail.com ${ }^{2}$ man.sunni@gmail.com
}

\begin{abstract}
Abstrak. Guru-guru MA Nurul Iman Mamben lauk berusaha melakukan pembelajaran sesuai dengan kurikulum 2013. Kurikulum 2013 yang telah dicanangkan Pemerintah untuk dilaksanakan disekolah mengalami berbagai kendala. Tujuan penelitian ini adalah untuk mengetahui dan memberikan gambaran tentang Pandangan guru MA Nurul Iman Mamben Lauk terhadap High Order Thingking Skill (HOTS). Penelitian yang dilakukan adalah penelitian Survey dengan analisis data menggunakan analisis deskriptif. Instrumen yang digunakan dalam penelitian ini merupakan angket tertutup yang dibagikan langsung kepada Responden. Hasil Penelitian menunjukkan bahwa $80 \%$ responden sudah mengetahui konsep HOTS sedangkan $20 \%$ belum. Selanjutnya $80 \%$ telah menerapkan pembelajaran berbasis HOTS dan $20 \%$ belum menerapkan. Sebesar 12,5\% merasa kurang dalam rujukan, kemudian 37.5\% merasa kesulitan dalam menyusun perangkat pembelajaran. Sebesar 50\% merasa kesulitan merancang dan mendapatkan media pembelajaran, dan 75\% merasa waktu yang dibutuhkan lebih banyak. Sebanyak 75\% merasa kesulitan dalam menyampaikan materi secara tepat dan $37.5 \%$ kesulitan dalam penyusunan bahan ajar. Kesulitan paling besar ada pada merancang evaluasi yaitu $100 \%$ responden merasa kesulitan.
\end{abstract}

Kata Kunci: Pembelajaran, HOTS, Persepsi guru

Abstract. MA Nurul Iman Mamben Lauq teachers try to do learning according to the 2013 curriculum. The 2013 curriculum that hasbeen announced by the Government to be implemented in schools has any troubles. The purpose of this study was to determine and provide an overview of the views of MA Nurul Iman Mamben Lauk teacher on High Order Thingking Skills (HOTS). This research is a survey research with data analysis using descriptive analysis. The instrument used in this study was a closed questionnaire which was distributed directly to respondents. The results showed that $80 \%$ of the respondents already knew the HOTS concept while $20 \%$ did not. Furthermore, $80 \%$ have implemented HOTS-based learning and $20 \%$ have not. $12.5 \%$ felt lacking in referrals, then $37.5 \%$ felt it was difficult to arrange learning tools. $50 \%$ find it difficult to design and get instructional media, and 75\% feel they need more time. As many as 75\% found it difficult to convey material appropriately and 37.5\% had difficulty in preparing teaching materials. The biggest difficulty was in designing the evaluation, namely $100 \%$ of respondents found it difficult

Keywords: Learning, HOTS, Teacher perception 


\section{PENDAHULUAN}

Kurikulum 2013 seharusnya sudah berjalan lebih dari 5 tahun sejak di tetapkan. Akan tetapi pada kenyataannya banyak guruguru yang menjadikan kurikulum 2013 hanya sebuah wacana saja. Pada pelaksanaan pembelajaran masih tetap berpatokan pada kurikulum lama. Hal ini sesuai dengan hasil wawancara terbatas dengan beberapa guru dari berbagai mata pelajaran di Kecamatan Wanasaba. Pada dasarnya, kurukulum 2013 sudah sangat di kiatkan oleh pemerintah baik pemerintah pusat maupun pemerintah daerah dalam bentuk pelatihan kepada guru. Pelatihanpelatihan tersebut di harapkan mampu meningkatkan kemampuan guru dalam melaksanakan kurikulum 2013. Kurikulum 2013 di anggap sebagai kebutuhan mendesak sehingga Mendikbud (2013) menyatakan bahwa jjika pelaksanaan kurikulum 2013 ditunda maka masa depan gene rasi muda bangsa Indonesia sebagai taruhannya.

Pentingnya kurikulum 2013 ini membuat pemerintah menekan seluruh sekolah untuk melaksanakannya secara maksimal. Pelaksanaan kurukulum 2013 menginginkan Sumber Daya Manusia (SDM) yang memiliki kualitas tinggi (Mustafa 2014). Dengan kemampuan SDM yang tinggi diharapkan membawa Indonesia mampu bersaing pada abad 21 dan pada Industrilisasi 4.0 sekarang ini. (Hidayati, 2018)Pada pelaksanaan kurikulum 2013 ini menekankan pada Keterampilan Berpikir Tingkat Tinggi yang lebih di kenal dengan sebutan HOTS. Pada kurikulum sebelumnya siswa masih di ajarkan untuk berpikir tingkat rendah atau Low Order Thingking Skill (LOTS). Pada pelaksanaan UNBK tahun 2018, soal-soal yang berikan sudah bebasis HOTS. Hal tersebut hampir menggoncang seluruh sekolah di tanah air karena para guru hanya berfokus mempersiapkan siswa untuk menyelesaikan soal LOTS.

Bedasarkan hasil observasi ke MA Nurul Iman didapatka bahwa sebagian besar guru mencoba melaksanakan kurikulum 2013 meskipun sebagian besar pembelajaran yang mereka lakukan masih lebih condong ke kurikulum sebelumnya yaitu KTSP. Berbagai kendala yang mereka hadapi menyebabkan Guru-guru lebih memilih untuk masih tetap menggunakan kurikulum KTSP dengan terus mencoba menerapkan kurikulum 2013.

Guru-guru membutuhkan pelatihanpelatihan khusus bagaimana menerapkan kurikulum 2013 atau dalam Hal ini pembelajaran berbasis HOTS. Pelatihanpelatihan yang dilaksanakan pemerintah tidak dapat dilakukan oleh semua guru. Guru-guru Madrasah yang berada di KOTA dapat dengan mudah mengetahui pelatihan-pelatihan mengenai suatu pembelajaran akan tetapi guruguru di desa memiliki kendala terhadap informasi mengenai pelatihan-pelatihan tersebut.

Membelajarkan siswa dengan HOTS tentu tidaklah mudah, guru harus memiliki kemampuan terlebih dahulu sebelum melaksanakannya. Guru harus di latih dan di gembleng sedemikian rupa sehingga dapat mengajarkan dengan baik kepada siswanya. Pemerintah perlu tahu sampai mana tingkat kemampuan guru dalam melaksanakannya dan kendala apa yang di hadapi sehingga dapat dicarikan solusinya secara tepat. permasalahan utama yaitu guru belum mengetahui bagaimana cara mengajarkan pembelajaran yang menuju HOTS (Rapih S. 2018). Sedangkan guru memiliki peranan penting dalam pelaksanaan pembelajaran agar dapat mencapai HOTS.

Pentingnya untuk menunjukkan kepada pihak-pihak yang berwenang atau pemangku kebijakan untuk mengetahui keadaan dari sekolah-sekolah dipedesaan mengenai kendala yang di hadapi dalam pelaksanaan pembelajaran yang sudah ditetapkan. Penelitian ini menjadi gambaran penting yang dapat menjadi panduan bagaimana salah satu sekolah Madrasah diwilayah tersebut dalam melaksanakan pembelajaran berbasis HOTS. 
Jurnal Ilmu Sosial dan Pendidikan

http://ejournal.mandalanursa.org/index.php/JISIP/index

Terakreditasi Peringkat 5 (No. SK: 85/M/KPT/2020)

\section{METODE PENELITIAN}

Penelitian ini menggunakan metode penelitian survey sedangkan pendekatan penelitian yang digunakan adalah deskritptif kuantitatif. Penelitian deskriptif merupakan suatu penelitian yang melakukan analisis hanya sampai pada taraf deskripsi, yaitu menganalisis dan menyajikan fakta secara sistematik agar dapat lebih mudah untuk difahami dan disimpulkan.

Instrumen dalam pengambilan data menggunakan kuisioner tertutup yang dibagikan langsung kepada responden oleh tim survey dengan mengikuti protocol kesehatan Covid 19. Angket yang diberikan terdiri dari 20 item pertanyaan. Selanjutnya, data dalam penlitian ini dianalisis dengan teknik analisis data deskriptif kuantitatif.

Populasi dalam penelitian ini adalah seluruh guru yang berada di MA Nurul Iman Mamben Lauq baik yang sudah memiliki NUPTK maupun yang belum. Teknik pengambilan sampel menggunakan purposive sampling dimana sampel diambil berdasarkan tujuan. Sampel yang didapat berjumlah 10 orang guru mata pelajaran MIPA yaitu guru Matematika, Biologi, Fisika dan Kimia.

\section{HASIL DAN PEMBAHASAN}

Hasil penelitian ini merupakan hasil pengolahan data penelitian dari angket yang telah disebarkan kepada 10 orang responden dengan berbagai karakteristik. Karakteristik responden yang dapat digambarkan adalah sebagai berikut:

\begin{tabular}{|l|l|l|l|}
\hline No & Data Responden & Jumlah & persentase \\
\hline 1 & Jenis kelamin & & \\
\hline & Laki-laki & 3 & $30 \%$ \\
\hline & perempuan & 6 & $70 \%$ \\
\hline & Total & 10 & $100 \%$ \\
\hline 2 & Usia & & \\
\hline & $25-30$ Tahun & 6 & $60 \%$ \\
\hline & $31-40$ Tahun & 3 & $30 \%$ \\
\hline & $41-50$ Tahun & 1 & $10 \%$ \\
\hline & Total & 10 & $100 \%$ \\
\hline 3 & Lama & & \\
\hline
\end{tabular}

Vol. 5. No. 1 Januari 2021 p-ISSN: 2598-9944 e-ISSN: 2656-6753

\begin{tabular}{|c|c|c|c|}
\hline & Mengajar & & \\
\hline & 1-5 tahun & 8 & $80 \%$ \\
\hline & 5-10 Tahun & 2 & $20 \%$ \\
\hline & Total & 10 & $100 \%$ \\
\hline 4 & $\begin{array}{l}\text { Pendidikan } \\
\text { Terakhir }\end{array}$ & & \\
\hline & $\mathrm{S} 1$ & 10 & $100 \%$ \\
\hline 5 & $\begin{array}{l}\text { Status } \\
\text { Sertifikasi guru }\end{array}$ & & \\
\hline & Tersertifikasi & 2 & $20 \%$ \\
\hline & $\begin{array}{l}\text { Belum } \\
\text { tersertifikasi }\end{array}$ & 8 & $80 \%$ \\
\hline & Total & 10 & $100 \%$ \\
\hline
\end{tabular}

Berdasarkan tabel karakteristik responden, didapatkan bahwa jumlah responden perempuan lebih besar dari pada responden laki-laki yaitu sejumlah 30\% laki-laki dan $70 \%$ perempuan. Meskipun terdapat perbandingan yang sangat besar pada jenis kelamin responden, akan tetapi belum ada penelitian menyatakan jenis kelamin memperngaruhi kinerja guru terhadap suatu pembelajaran terutama pembelajaran berbasis HOTS.

Pengalaman mengajar guru terdiri dari 1-5 Tahun sebanyak $80 \%$ sedangkan responden yang mengajar selama 5-10 tahun hanya $20 \%$. Sebagian guru yang mengajar adalah guru muda yang memiliki kesempatan untuk berkembang. hal tersebut dilihat dari jumlah guru yang memiliki rentang usia 25-30 tahun sebanyak 6 guru dan guru yang memiliki usia 30-40 tahun sebanyak 3 guru sedangkan guru senior yang memiliki usia 40-50 tahun hanya 1 orang. Semua responden memiliki ijazah terakhir sarjana S1, akan tetapi karena sebagian besar masih muda maka ada kesempatan untuk dapat melanjutkan ke jenjang S2 bahkan S3.

\section{Pemahaman guru terhadap pembelajaran High Order Thinking Skill (HOTS)}

Berdasarkan jawaban dari responden, sebanyak 8 orang atau $80 \%$ menjawab sudah memahami pembelajaran dengan HOTS, sedangkan 2 orang atau 20\% mengatakan tidak. Dari hasil wawancara singkat diketahui bahwa guru tersebut masih merasa kebingungan 
bagaimana konsep HOTS yang sebenarnya. Hal tersebut karena kurangnya pelatihan-pelatihan yang diikuti bahkan ada sebagian guru yang sama sekali tidak pernah mengikuti pelatihan tentang HOTS. Guru yang tidak mengikuti pelatihan mengaku lihat dan baca sekilas pandang tentang HOTS melalui laman internet. Hasil dari membaca dari laman internet tersebut mereka gunakan sebagai acuan untuk melaksanakan pembelajaran berbasis HOTS. Seperti halnya penelitian yang dilakukan oleh Rapih, S. dan Sutaryadi (2018) dimana masih terdapat guru yang belum mengetahui konsep dari HOTS.

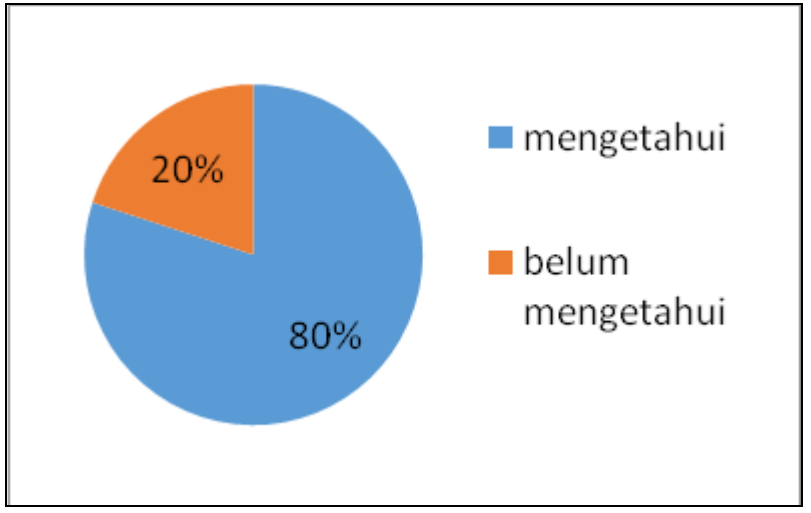

Gambar 1. Persentase pemahaman konsep HOTS

Pentingnya pemahaman guru terhadap pembelajaran High Order Thingking Skill menjadi syarat mutlak. Jika guru tidak paham maka pembelajaran tidak akan berjalan dengan baik atau benar. Hal tersebut sejalan dengan pendapat Rapih, S \& Sutaryadi yang juga mengemukan jika tidak mengetahui konsep bisa dipastikan tidak akan bisa menerapkan pembelajaran berbasiskan HOTS. Konsep yang dimiliki guru akan mengarahkan guru untuk memilih strategi, model, metode dan atau media pembelajaran yang akan digunakan. Seperti pendapat Eggen \& Kauchak (2012) yang menyatakan bahwa kemampuan siswa untuk mensintesis, mengevaluasi dan menerapkan ilmu pengetahuan yang dimiliki ditentukan pula oleh beberapa faktor lain diantaranya model, metode, pendekatan dan strategi pembelajaran, dan sejumlah faktor yang juga mempengaruhi hasil pembelajaran.
Kurangnya pengetahuan guru terhadap konsep HOTS menjadi tanggung jawab bersama, akan tetapi tentu menjadi PR besar bagi Depag setempat yang menaungi Madrasah Berbasis Madrasah untuk mengadakan pelatihan-pelatihan secara berkala untuk meningkatkan kemampuan guru terkait HOTS. Pelatihan-pelatihan harus menjangkau daerahdaerah yang diluar perkotaan salah satunya MA Nurul Iman Mamben Lauq dimana guru-guru merasa tidak banyak mengetahui informasi terkait pelatihan-pelatihan yang diadakan.

\section{Persepsi guru terhadap penerapan pembelajaran berbasis HOTS}

Responden diberikan pertanyaan mengenai implementasi pembelajaran berbasis HOTS pada pembelajaran yang telah dilakukan. Implementasi yang dimaksud tidak harus secara sempurna. Meskipun responden hanya menerapkan pembelajaran HOTS tidak secara menyeluruh maka tetap dianggap sebagai melaksanakan pembelajaran HOTS. Implementasi yang dimaksud disini mencakup mencakup kegiatan perencanaan, penerapan dan evaluasi pembelajaran. Dari hasil survey di dapatkan bahwa sebanyak $80 \%$ respponden melaksanakan pembelajaran HOTS dan sebanyak $20 \%$ belum melaksanakan pembelajaran berbasis HOTS.

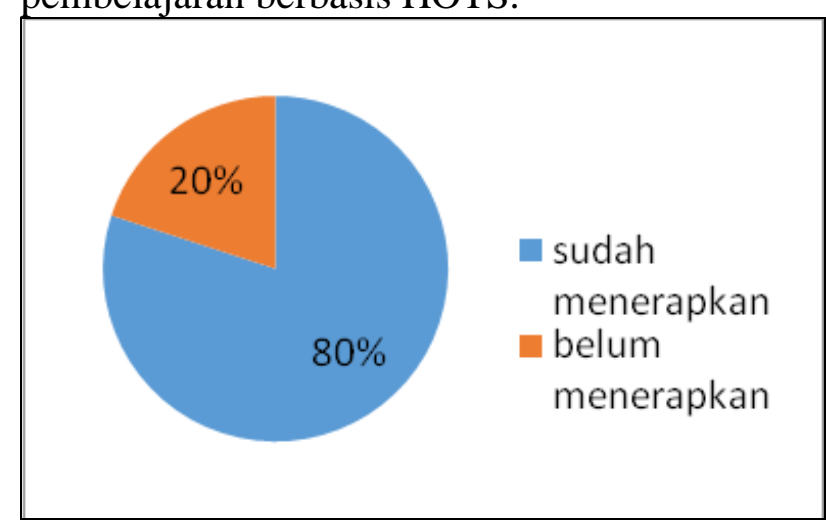

Gambar 2. Persentase penerapan pembelajaran berbasis HOTS 


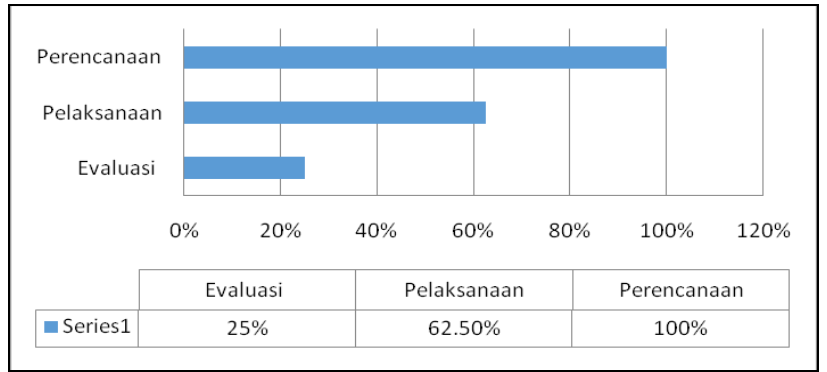

Gambar 3. Jenis kegiatan pembelajaran yang menerapkan HOTS

Berdasarkan hasil tersebut memperlihatkan bahwa mayoritas guru MA Nurul Iman Mamben Lauk sudah mulai menerapkan pembelajaran berbasis HOTS. Meskipun pembelajaran berbasis HOTS belum sepenuhnya diterapkan akan tetapi sudah merupakan angin segar sehingga guru tinggal diarahkan untuk dapat melaksanakan pembelajaran berbasis HOTS secara menyeluruh.

Seluruh Responden yang melaksanakan pembelajaran berbasis HOTS telah menanamkan nilai-nilai HOTS pada level perencanaan atau $100 \%$. Sedangkan yang menerapkan nilai HOTS pada Level pelaksanaan hanya $62,5 \%$ dan yang pernah sampai pada level evaluasi hanya $25 \%$. Banyaknya guru yang sudah membuat perencanaan pembelajaran berbasis HOTS karena penyusunan perangkat pembelajaran merupakan jenis kegiatan yang paling mudah dalam implementasi nilai-nilai HOTS (Rapih, S $\&$ Sutaryadi). Sedangkan pada tahap evaluasi hanya $25 \%$ guru yang mampu melaksanakannya. Artinya guru masih sangat kesulitan pada tahap ini sehingga perlu perhatian khusus.

\section{Persepsi guru terhadap kendala penerapan pembelajaran berbasis HOTS}

Pada proses pembelajaran berbasis HOTS terdapat berbagai kendala yang dihadapi oleh guru. Setiap guru bahakn memiliki lebih dari satu kendala yang menyebabkan kurang maksimalnya pelaksanaan pembelajaran. Dari 8 orang yang telah melaksanakan pembelajaran berbasis HOTS terdapat 1 orang atau $12.5 \%$ merasa terkendala pada rujukan. Kesulitan rujukan yang sesuai dengan karakteristik siswa dan keadaan sekolah menjadi alasannya. . Kurangnya referensi menyebabkan responden merasa kebingungan untuk memilih metode dan media yang cocok untuk materi ajar yang akan disampaikan akan tetapi tetap berusaha melaksanakan pembelajaran berbasis HOTS.

Pada proses penyususan perangkat pembelajaran sebanyak $37.5 \%$ atau 3 responden yang telah melaksanakan merasa kesulitan karena kurangnya pengalaman. Selanjutnya media pembelajaran juga menjadi kendala bagi sebagian responden, dimana sebanyak $50 \%$ atau 4 responden merasa kesulitan menemukan media dalam proses mengajar dengan pembelajaran berbasis HOTS, karena sebelumnya hanya menggunakan sistem ceramah dan dengan sedikit media sederhana yang ada di Madrasah. Penggunaan media pembelajaran sangat penting terutama pada mata pelajaran yang membutuhkan praktikum seperti halnya fisika, kimia dan biologi. Kurangnya sarana dan prasarana yang dimiliki oleh Madrasah seperti laboratorium, menjadi kendala besar bagi guru sehingga guru harus kreatif menyediakan media sendiri yang terjangkau.

Kesulitan atau kendala yang dihadapi guru juga terletak pada penyampaian materi yaitu sebanyak 75\%. Guru harus mampu menyampaikan materi secara singkat akan tetapi mambuat siswa merasa antusias dan memiliki ketertarikan terhadap materi yang diajarkan. Guru harus mampu memberikan gambaran materi sehingga siswa dapat mensistesis pengetahuannya kemudian mampu membuat opini dan menyelesaikan masalah yang didapat. Akan tetapi guru masih kesulitan mengarahkan siswa untuk lebih aktif dan mau bekerja sama.

Waktu atau jam pelajaran juga merupakan kendala yang besar. $75 \%$ atau 6 orang merasa terkendala pada waktu. Waktu yang dibutuhkan untuk pembelajaran berbasis HOTS menjadi dua kali lebih banyak dibandingkan dengan pembelajaran berbasis LOTS. Siswa dan guru 
belum terbiasa untuk proses berpikir yang lebih tinggi, sehingga waktu menjadi molor dari yang ditargetkan. Waktu yang molor akan menyebabkan keterlambatan dalam menerima materi selanjutnya yang sudah di tetapkan dalam kurikulum. Hal tersebut menjadi kerisauan pada guru dimana ditekankan untuk melaksanakan pembelajaran berbasis HOTS akan tetapi tidak memiliki kebebasan dalam waktu pembelajaran.

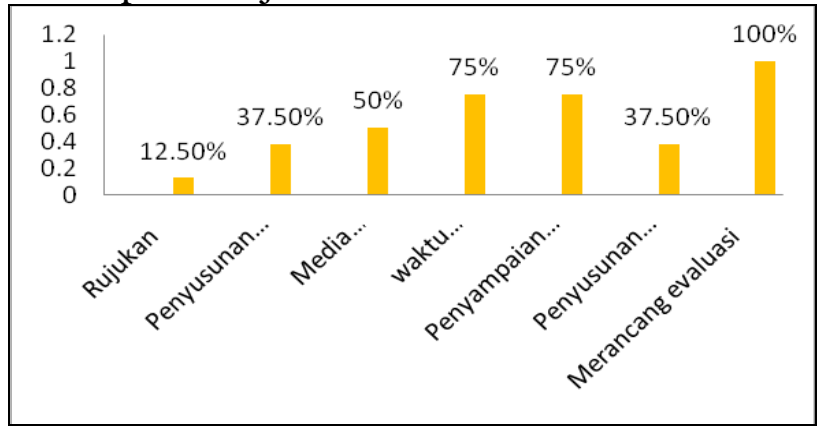

Gambar 4. Kendala Yang dihadapi dalam menerapkan HOTS

Waktu yang dibutuhkan ketika mengajarkan siswa dengan pembelajaran low order thingking skill (LOTS) berbeda dengan pembelajaran berbasis HOTS. Sebagian besar guru MA Nurul Iman Mamben Lauk menyatakan membutuhkan waktu lebih lama dalam melaksanakan pembelajaran berbasis High Order Thingking Skill (HOTS). Belum terbiasanya baik guru maupun siswa menjadi alasan utama meskipun dalam proses pembelajran belum $100 \%$ berbasis HOTS. Proses pembelajaran dimana siswa harus menemukan sendiri masalah dan kemudian menyelesaikannya menunutut siswa untuk tekun dan dan bekerja keras menemukan solusi dari permasalahan yang di hadapi tidak hanya menunggu penyelesaian yang diberikan oleh guru kemudian menghapalkan atau menirunya. Proses berpikir yang baru ini membuat sebagian besar siswa terkaget sehingga membutuhkan waktu lama dalam setiap proses pembelajaran. Sebagian lagi merasa tertantang sehingga lebih antusias. Waktu yang dibutuhkan siswa tidak sedikit, diperlukan waktu untuk merenung, berinteraksi, menanyakan, membenarkan, dll
(Widodo Tri \& Kadarwati Sri, 2013) sehingga wajar saja guru menganggap waktu pembelajaran sebagai salah satu kendala yang dihadapi.

Responden yang terkendala pada Penyusunan bahan ajar sebanyak $37.5 \%$ atau sebanyak 3 responden. Selanjutnya kendala yang paling banyak dihadapi oleh guru adalah pada bagian evaluasi pembelajaran berbasis HOTS. Meskipun telah melaksanakan perencanaan dan proses pembelajaran berbasis HOTS akan tetapi sebagian besar guru belum melakukan evaluasi yang sesuai dengan nilai HOTS. Guru belum mampu merancang sendiri evaluasi pembelajaran yang mereka lakukan dan sulit mendapatkan evaluasi yang telah tersedia agar cocok dengan pembelajaran berbasis HOTS. Belum banyaknya evaluasievaluasi yang berkaitan dengan pembelajaran berbasis HOTS tentu menjadi kendala besar yang harus diatasi.

\section{KESIMPULAN}

Dari hasil penelitian ini dapat disimpulkan bahwa :

1. Terdapat $80 \%$ responden/ guru yang telah memahami konsep pembelajaran berbasis HOTS sedangkan yang belum memahami sebesar $20 \%$.

2. Sebesar 70\% responden/ guru telah menerapkan pembelajaran HOTS meskipun hanya pada salah satu kegiatan (perencanaan, pelaksanaan atau evaluasi) saja. Sedangkan sebesar 30\% merasa belum melaksanakan pembelajaran berbasis HOTS.

3. Pembelajaran berbasis HOTS memiliki beberapa kendala seperti rujukan, penyusunan perangkat pembelajaran, penyampaian materi, media pembelajaran, merancang evaluasi, waktu yang dibutuhkan, serta evaluasi pembelajaran.

DAFTAR PUSTAKA

Chinedu, C.C. \& Kamin, Y (2015). Strategies For Improving Higher Order Thinking 
Skills In Teaching And Learning Of Design And Technology Education. Journal of Technical Education and Training (JTET). Vol. 7, No.2

Eggen, P \& Kauchak, D. 2012. Strategic and Models for Teaching Content and Thinking Skills, Sixth Edition (Eds): Boston. Perason Education, Inc.

Hidayati, A. U. (2018). Melatih Keterampilan Berpikir Tingkat Tinggi Dalam Pembelajaran Matematika Pada Siswa Sekolah Dasar. Terampil: Jurnal Pendidikan Dan Pembelajaran Dasar, 4(2), 143156

http://e-journal.unipma.ac.id

Kusuma, Merta D. dkk.2017.The Development of Higher Order Thinking Skill (Hots) Instrument Assessment In Physics Study. IOSR Journal of Research \& Method in Education (IOSR-JRME). Volume 7, Issue 1

Limbach \& Waugh. (2010) Developing Higher Level Thinking. Journal ofInstructional Pedagogies, 1-9.

Mustafa, Kasmudin. 2014. Pengaruh Strategi Pembelajaran terhadap Kemampuan Berpikir Tingkat Tinggi. Jurnal Pendidikan Humaniora. Vol. 2 No. 4 http://journal.um.ac.id

Nurhaini. 2014.Analisis Persepsi Guru Dan Peserta Didik Terhadap Kualitas Bahan Ajar. Jurnal Sains dan Pendidikan Fisika. Jilid 10, Nomor 3

Rapih, S. \& Sutaryadi.2018. Perpektif guru sekolah dasar terhadap Higher Order Tinking Skills (HOTS): pemahaman, penerapan dan hambatan. Premiere Educandum Vol. 8 No.1

Tan Shin Yen \& Siti Hajar Halili.2015. Effective Teaching Of Higher-Order Thinking (Hot) In Education. The Online Journal of Distance Education and e-Learning. Volume 3, Issue 2

Tri widodo dan Sri Kadarwati. 2013. Higher
Order Thinking Berbasis Pemecahan Masalah Untuk Meningkatkan Hasil Belajar Berorientasi Pembentukan Karakter Siswa. Cakrawala Pendidikan Volume 32 No 1 www.tojdel.net

Yee, M. H., Lai, C. S., Tee, T. K., \& Mohamad, M. M. (2016). The Role of Higher Order Thinking Skills in Green Skill Development. EDP Sciences, 70(5001), 1-5. 